Article

\title{
Demand and Deliver: Refugee Support Organisations in Austria
}

\author{
Sara de Jong ${ }^{1, *}$ and Illker Ataç ${ }^{2, *}$ \\ ${ }^{1}$ Citizenship \& Governance SRA, The Open University, Milton Keynes, MK7 6BH, UK; E-Mail: sara.dejong@open.ac.uk \\ 2 Department of Political Science, University of Vienna, 1010 Vienna, Austria; E-Mail: ilker.atac@univie.ac.at \\ * Corresponding authors
}

Submitted: 30 April 2017 | Accepted: 10 August 2017 | Published: 19 September 2017

\begin{abstract}
This article analyses four emerging refugee support organisations in Austria, founded before the so-called refugee crisis in 2015. It argues that these organisations have managed to occupy a middle space between mainstream NGOs and social movements with structures of inclusive governance, a high degree of autonomy, personalised relationships with refugees, and radical critique combined with service delivery. Based on interviews with the founders of each organisation, we show that their previous NGO and social movement experience formed a springboard for the new initiatives. It not only allowed them to identify significant gaps in existing service provision, but also provided the space of confrontation with the asylum system inspiring a strong sense of outrage, which in turn developed into political critique. We argue that this critique combined with identifying the needs of asylum seekers and refugees has produced a new type of organisation, which both delivers services and articulates radical demands. Each organisation offers a space of encounter, which undoes the 'organised disintegration' of the asylum system.
\end{abstract}

\section{Keywords}

asylum seekers; Austria; autonomy; civil society; funding; governance; NGOs; refugees; social movements

\section{Issue}

This article is part of the issue "Perspectives on the European Border Regime: Mobilization, Contestation, and the Role of Civil Society", edited by Ove Sutter and Eva Youkhana (University of Bonn, Germany).

(C) 2017 by the authors; licensee Cogitatio (Lisbon, Portugal). This article is licensed under a Creative Commons Attribution 4.0 International License (CC BY).

\section{Introduction}

In the summer of 2015, Austria suddenly found itself in the limelight of international attention against the backdrop of the large inflow of people fleeing from wars, travelling over land via Eastern Europe and the Balkans. Voluntary organisations and initiatives responded rapidly to increasing numbers of asylum seekers and to changing local needs, especially in a context where limited resources and unclear policies kept governmental actors and established NGOs from providing adequate administration and services. While the scale of the issue and the fact that it exposed a fundamental solidarity crisis in Europe warranted some special attention, it is important to remember that asylum seekers are not new to Austria. Indeed, the "impressive civil society mobilization for solidarity with refugees" that Europe witnessed as an initial response (Bauböck \& Scholten, 2016, p. 2), has roots in earlier practices of activism. At the time, Austria, and especially Vienna, already had a diverse landscape of established NGOs and smaller organisations supporting refugees and asylum seekers.

This article offers an analysis of the organisational histories and principles of four refugee support initiatives, Flucht nach Vorn, KAMA, PROSA, and Queer Base, established within the last decade in Vienna. All four quickly developed into respected players in the field of refugee support. In the summer of 2015, these relatively young initiatives already had an emerging infrastructure and could respond to and adapt themselves in the face of the new challenges. The aim of the research was to find out what principles and practices inspired these four initiatives, and why they were set up as autonomous organisations, rather than integrated as projects in the existing 
refugee support sector. Our investigation was led by two research questions. First, where can the four recent initiatives be situated in relation to the existing refugee and asylum support field, as mapped out in the literature on NGOs, social movements and migrant self-organisations? Second, in what way, if at all, are these initiatives challenging and transforming the established field of refugee and asylum support? In this article, we argue that these four initatives created innovative organisations that combined service delivery with an articulation of demands for radical change. Before we elaborate this argument and introduce the theoretical framework, we provide a brief overview of the Austrian asylum and refugee support sector and the four initiatives.

For this exploratory study, we analysed the transcripts of semi-structured interviews with two founders of each organisation $(n=8)$, as well as organisational literature and printed and online media about the initiatives. The interviews with these key informants, all of whom were interviewed separately, lasted approximately two hours and took place in spring 2016. Through the interviews we sought to capture the "organisational biography"; the life-story of an organisation from its inception to its subsequent stages of development (Fairbairn, 2001, p. 25). We therefore addressed initial motivations for setting up the organisation, the way it evolved, as well as key turning points in the organisational history, organisational principles, the nature of relationships with asylum seekers and refugees, dilemmas or conflicts and, finally, future plans. In the first coding cycle, the authors co-developed codes to capture common patterns and characteristics and jointly refined the codes in the second cycle to analyse the data in more detail with qualitative data analysis software. The quotes that we use to illustrate our analysis have been translated by the authors from German to English. In order to ensure a degree of confidentiality, we omit the names of the research participants and only refer to the names of the initiatives.

\section{The Refugee and Asylum Support Sector in Austria}

Similar to the UK refugee system, which also is an "interorganizational domain" with various organisations with different and sometimes conflicting principles (Phillips \& Hardy, 1997, p. 159), Austria's asylum and refugee support sector is diverse. New refugee support associations emerged in the course of the 1990s against the background of more politicised discussions on asylum issues and more restrictive asylum legislation. The most important independent initiatives in the field are Flüchtlings- und Deserteursberatung (Refugeeand Deserter-Counselling Service) and Asyl in Not (Asylum in Peril) in Vienna, and the association Fluchtpunkt in Innsbruck that offers mainly counselling services for asylum seekers and undocumented migrants. Nevertheless, church-related humanitarian organisations such as Caritas and Diakonie, together with other major or- ganisations like Volkshilfe and the Rotes Kreuz dominate the asylum and refugee sector. In the course of the last decade, commercial private service companies emerged as well as "gongos" (Government-OrganisedNon-Governmental-Organisations), such as the Verein Menschenrechte Österreich. In Austria, the city of Vienna remains the centre of the refugee and asylum sector; the nationally organised quota system that should distribute asylum seekers per province (Bundesland) is effectively blocked at regional and local levels, thus Vienna is the only region that fulfils and exceeds the quota (OE1, 2014).

Langthaler and Trauner (2009, p. 454) found that there is almost no cooperation between self-organised refugee associations and NGOs that offer services for asylum seekers and refugees (cf. Cullen, 2009, for a similar observation in the Irish context). One exceptional event that brought these organisations together was the Refugee Protest Camp Vienna. It started in 2012 as a protest against the living conditions of asylum seekers, and turned into a highly visible protest movement organised by asylum seekers, supporters and activists. The protest movement created their own social spaces, which produced emotional solidarity ties among the refugees, as well as between refugees, NGOs and supporters (Ataç, 2016). As the established NGOs, such as Caritas, as well as the unconventional radical initiatives created alliances with protesting refugees, conflicts emerged around the aims of the protest and questions such as whether established NGOs were trying to co-opt the movement by reducing their radical demands and making them into objects rather than political subjects.

The four self-organised initiatives that are the focus of this article complement the work of the established NGOs. They differ from other, older autonomous organisations, which offer counselling services, because they offer services that relate strongly to the social rather than legal needs of asylum seekers. Each of these four initiatives, introduced below, witnessed rapid expansion and soon received recognition for their work by the established NGO field as well as the Austrian state.

The organisation KAMA was founded in 2007 in Vienna. KAMA is the abbreviation of "Kurse von Asylsuchenden, MigrantInnen und Asylberechtigten", translated as "Courses by asylum seekers, migrants and persons granted asylum". Its main goal is to facilitate courses offered by asylum seekers in which they share their skills (linguistic, culinary, musical, etc.) with the broader public. The courses are free of charge, but participants can pay a donation. Starting in Vienna, KAMA spread to other cities: Linz and Graz in 2014, Innsbruck and Salzburg in 2015. In 2013, KAMA was awarded the third prize in the Social Integration category of the ERSTE Foundation (25,000 Euros). The project is currently mainly financed through donations and based on volunteer work (Erste Stiftung, 2013).

The project PROSA stands for "Projekt Schule für Alle!" (Project: School for all!). Since 2012, PROSA has of- 
fered courses to adolescent asylum seekers and refugees to finish secondary education, given that those over 16 years of age fall outside compulsory education in Austria. In September 2014, PROSA opened its own space for education, events, communication and encounter, called Café PROSA. In 2015, the project was financed through personal donations, through membership fees, as well as through a number of awards. For example, in 2015, they were awarded the SozialMarie, a European price for social innovation (Mauch, 2015).

Flucht nach Vorn is an association that organises leisure activities for minors and young adults in the fields of sports, arts, culture, music and education. Through these activities, young refugees can enter into an exchange with the "majority society". The idea was born in 2012; in spring 2013, the first event took place. In 2017, they opened their own space, a cultural centre, and in 2015 they received the Ute-Bock-Preis für Zivilcourage, a renowned Austrian price for civil society work.

Queer Base, founded in 2015, is the only initiative that was developed in the context of an established organisation, the Türkis Rosa Lila Villa for the Lesbian, Gay, Bisexual, Transgender, Queer and Intersex (LGBTQI) community. It has, however, an independent organisational structure. First, the organisation was mostly based on donations and volunteer activism. Later, the city council offered financial support to Queer Base. The organisation offers safe shelter, legal advice and peer-to-peer counselling, as well as a buddy system. In 2017, they received the Bruno Kreisky Prize for Human Rights.

\section{Movements and Organisations}

Civil society action in relation to migration, and in this case, refugees and asylum seekers specifically, emerges from a diverse field comprised of social movements, NGOs and refugee and migrant community organisations. Civil society's actions range from anti-immigration movements to pro-immigration groups, which cover a range of activities, from grass-rooted activism, the delivery of basic services for vulnerable immigrant groups, to advocacy organisations (Ambrosini \& Van der Leun, 2015). The different organisational structures and political strategies of NGOs and social movements have frequently led to tensions. Petras, in a damning Marxist critique, has noted that in contrast to social movements, NGOs "emphasize projects not movements" and concentrate on technical assistance or service delivery over engagement with the "structural conditions that shape the everyday lives of people" (1999, p. 434). In slightly milder language, Alejandro Bendaña describes how social movements

develop an organizing dynamic quite different from the networking carried out by entities fundamentally dedicated to policy advocacy, service delivery and monitoring, which are characteristic of many NGOs. That circumspection, or absence of a social base, in turn influences the degree of dependence on exter- nal funding and with it the need to take positions that do not upset the funders. $(2006$, p. 21)

Evaluating activities of civil society organisations in the field of migration and asylum governance, we can distinguish between a 'problem-solving-approach' and a 'critical-approach', depending on the respective aims of the organisation, its relation to policy actors and to $\mathrm{mi}-$ grants and refugees, as well as its organisational form (Ataç, 2015). 'Problem-solving' activities offer services for asylum seekers and migrants such as consulting, shelter and social services, which are often financed by federal and local governmental bodies. In the context of limited resources, the question arises whether governmental bodies intentionally use the participation of civil society organisations in order to fill the gap of public service provision with cheaper offers in a field that is increasingly dominated by market-oriented competition (Van Dyk \& Misbach, 2016). This strengthening of ties between the state and the voluntary sector through subcontracting also limits the space for political agitation (Bloch \& Schuster, 2002; McGee \& Walker, 2016). In contrast, civil society activities categorised as belonging to a 'critical' approach include social movements, self-organised groups and NGOs, which express solidarity with migrants and refugees, conduct advocacy for their rights, campaign for pro-migration policies, and put political pressure on the government (Vickers, 2014). Finally, there are also organisations that represent a mix of both approaches, offering services as well as campaigning for improvements in the political framework (Castañeda, 2013; Mora \& Handmaker, 2014).

A second form of division that marks the refugee and asylum support sector (and the migrant support sector broadly) is that between what Cullen (2009) describes as majority-led pro-migrant organisations on the one hand, and grassroots migrant-led organisations on the other. The first are usually more formalised and have a closer relation to the state and related resources (Cullen, 2009). The latter, as self-organised organisations, are usually based on a close relation between 'members' based on shared nationality, ethnicity, migration status, religion and regional origin or a combination thereof (Piacentini, 2015), reducing or even annulling the gap between providers and service-users (Martin, 2014). In the competition for direct and indirect state funding, grassroots migrant-led organisations that are new to the field, often lose out against more established organisations (Mackenzie, Forde, \& Ciupijus, 2012).

To an extent the different types of organisation, migrant-led on the one hand, and majority-led, on the other hand, can be mapped onto the tensions between social movements and NGOs. For instance, grassroots migrant-led organisations, or Migrant and Refugee Community Organisations (MRCOs) as they are called in the UK context, share features with social movements in that they often rely on voluntary engagement and have structures of self-governance and close links to the commu- 
nity. Majority-led pro-migrant organisations, in contrast, including those in Austria, often lack representation of migrants in the organisation, especially in management and coordination roles, and therefore have the tenuous accountability structures associated with NGOs (de Jong, 2017a). However, the tension between grassroots migrant-led organisations or MRCOs and majority-led organisations should not simply be equated with that between social movements and NGOs. Migrant-led organisations often become more formalised NGOs and are frequently engaged in service provision rather than political mobilisation (Bloch \& Schuster, 2002). Moreover, the differences between social movements and NGOs should not detract from the fact that they also face similar dilemmas, for instance ones concerning the relationship to their social base. No Border movements, for instance, also wrestle with questions such as "Should advocates relate to non-status immigrants as clients or as allies?" (Nyers, 2003, p. 1081).

Hence, in a slightly simplified manner, five interrelated core areas of contention can be identified: 1) autonomy versus dependency on funders; 2) voluntary activism versus paid professionalism; 3 ) radical change versus reformism; 4) political mobilisation versus service delivery; and finally, 5) self-governance and accountability to the social base versus expert or formal governance.

Both the distinction between social movements and NGOs and between majority-led pro-migrant organisations and grassroots migrant-led organisations should be treated as generalising characterisations that are helpful to map the broad contours of and tensions within civil society action in relation to migration. However, as we show, the recent initiatives investigated in this article position themselves in relation to these tensions, while simultaneously problematising this typology.

\section{New Refugee Support Organisations between NGOs and Civil Society}

\subsection{Funding, Autonomy, Voluntarism and Professionalisation}

The four initiatives were each set up as a new autonomous organisation rather than integrated as programmes in existing migration support structures. This was remarkable, since many of the founders had experience in established organisations. In fact, it was often this experience that formed the inspiration to set up their own organisations. As the research participants recalled, they were confronted with the realities of the asylum system through formal employment or internships, and discovered a gap in the existing service provisions.

For example, remembering the early days of Flucht nach Vorn, the founder explained that a sudden increase in the number of unaccompanied minors posed a challenge for established organisations offering services to this group. At this time, she was working as an interpreter for an NGO that offered psychological support.
Her work, which included translation, alerted her to the specific problems of unaccompanied minors. While they were fortunate to have access to psychological services, there was no form of supervision or activity outside the programme. Witnessing how the lack of social contacts and boredom led to depression, inspired her to establish Flucht nach Vorn with the goal to offer leisure activities to this group.

The founder of PROSA was working as an education counsellor for an established NGO in a town in Lower Austria. Working in a geographically isolated asylum accommodation centre, he realised that adolescent asylum seekers have very limited access to education. He suggested developing an alternative educational project to his employer-however, the organisation rejected the idea. Consequently, he decided to set up a project as an independent organisation, together with friends who were part of his social and political network. This narrative is also echoed in the founding history of KAMA. The founder studied Social Work and worked during her studies as a volunteer in another well-known NGO, which supports and offers services to irregular migrants outside of the asylum reception system. Through this work, she became aware of the living conditions of irregularised migrants and rejected asylum seekers. While the NGO she volunteered for, fulfilled the basic needs of shelter and food, it did not address issues of employment. Since access to the labour market is very restricted for asylum seekers (UNDOK, 2017) and also those with refugee status face significant obstacles (de Jong, 2017a), she developed the idea of $K A M A$ as a way to support refugees and asylum seekers in offering courses in which they could share their skills.

The space that the initiatives sought to occupy demanded tightrope walking between the lure of institutionalisation, professionalisation and service delivery on the one hand, and autonomy, voluntarism, and protest on the other hand. When articulating their principles, the founders that we interviewed frequently referred to the large NGOs (notably Caritas, Volkshilfe, Diakonie and Rotes Kreuz) as a way to distinguish their own initiatives. This reflects the tensions addressed above, which describes how social initiatives that become institutionalised as NGOs lose their autonomy due to dependence on direct and indirect state funding, increasing susceptibility to co-optation. As Mackenzie et al. observe, "there is a risk that the institutional goals of...organisations, in terms of securing resources and influence, may take precedence over substantive goals of support provision" (2012, p. 632). From the interviews it became clear that the founders' decision to set up autonomous organisations, rather than programmes integrated in the existing NGO sector was partly based on the desire to resist this risk.

A KAMA founder reinforces the point that lack of funding and embeddedness in the Austrian mainstream NGO scene, provides KAMA with an important degree of autonomy. She explained that there have been internal organisational discussions about the possibility to em- 
bed the organisation in the structures of Caritas or Volkshilfe. However, this would mean that, "we would not be as free anymore. Now we can do what we want." She reinforces the point of autonomy also in relation to funders' requirements: "What you all have to change to be worthy of funding...that leaves no longer any free space." This shows her awareness that increased formalisation has an "opportunity cost in terms of spending time and resources in pursuit of funding at the expense of actually providing support" (Mackenzie et al., 2012, p. 634).

A PROSA founder echoed this sentiment:

We have to...have the courage to insist on things, also when there is a risk that we don't get it funded.... [The logic that] we first need financial means to set up projects, that is a logic that other [organisations] already have, we don't need any more of that. One should, I think, do it and then one should look how can it be financed.

One of the Flucht nach Vorn founders focussed her reflections vis-à-vis funding relations and autonomy on political parties, given the fact that some of the large mainstream NGOs in the Austrian migration sector have strong links to political parties. As she explained:

From parties or governments, we did not want any support, for various reasons. First we did not want to be embraced by them, second we did not want to lose the trust of our clients, because they have often fled for political parties, or also here [in Austria] suffered depressions or were threatened by deportation....And we have always tried to work with ethical and morally acceptable funders or with private donations.

Funding, and especially the refusal of certain types of funding and its concomitant dependencies, made possible by a strong reliance on both voluntary engagement and prize money, was therefore crucial to the way the founders described the principle of autonomy of their organisations. One KAMA founder succinctly expressed the significance of this for the organisation's identity: "Who knows who we would be, if we would work with money." Receiving funding was therefore regarded as a 'mixed blessing'; one that opened but potentially also closed off certain avenues and would risk fundamentally altering the organisation.

Yet most of the organisations that we studied collaborated in some way with the established NGOs. That their own position and principles were tied to a rejection of some of the deficiencies of NGOs that they named, did not mean an unequivocal rejection of such NGOs. Neither did it mean a complete alignment with social movements as an alternative form of intervention. One Queer Base founder we interviewed explained it eloquently this way:

We originate from a social movement, but we are too much confronted with concrete situations....We can- not afford to be only idealistic. We therefore should collaborate with people and with organisations, we don't have to, but it makes sense, to collaborate with people or organisations, with whom as a social movement I might not align myself. Because I would say, I don't want to have anything to do with them, etc. But on the other hand, from an organisation like Caritas or Diakonie, I am very far removed, because we are too much a social movement for that.

In fact, a year after the interview was conducted, the founder reflected back on her earlier position and explained that the ties with these established large NGOs had strengthened in the last year and that the organisation had depended on them for its survival. At this point in time, she regarded the collaboration as fruitful as it affected a change in perspective on the position of LGBTQI asylum seekers and refugees within mainstream NGOs (email correspondence June 2017, cf. facebook post 27.06 .2017$)$. She provocatively countered the idea that they would be swallowed up by these larger NGOs, with the question 'who is eating whom?' (email correspondence June 2017, cf. facebook post 27.06.2017). Indeed, clear commitment to a goal can "act as a counterbalance to bureaucratisation, allowing social movements to sustain a more radical agenda against pressures to become more conservative and thus mainstream" (MacKenzie et al., 2012, p. 635).

A PROSA founder echoed Queer Base's ambition to combine idealism with pragmatism. She recalled that she was once asked during a panel discussion whether taking over the responsibility of the state was the right political approach, and that she answered: "not right, but necessary." This reply, in fact, is not dissimilar from the principle of an established NGO in the Austrian migration sector, the evangelical Christian NGO Diakonie, which emphasises that they offer "support under protest", demanding change in the conditions that necessitate support (Diakonie, 2017).

The tightrope walking in the space of civil society requires constant readjustment and vigilance in response to changing circumstances. The interviews took place at a time when the initiatives were increasingly successful and were gaining recognition, which meant that funding became more readily accessible. For organisations that had initially solely run on the basis of intensive, unpaid labour (not unfrequently leading to symptoms of burn-out), and that had connected this to their sense of autonomy, this meant considering what the introduction of paid staff members would mean. This was especially poignant since they associated paid professionalised work with the mainstream NGOs that they wanted to distinguish themselves from. One PROSA founder sketched this contrast as follows:

There are these very large organisations like Volkshilfe, Diakonie and Caritas, but these are professional organisations. Not in the sense of doing their work 
better in some way, but that they do it with a professional background, these are paid people, who are trained for exactly this area of work. Personally, they probably enjoy their work, but I believe that this personal, individual engagement is not foregrounded like in our case.

A Queer Base founder, who pondered aloud about their recent success in obtaining funding, which would enable them to remunerate some activists for their work, shared similar reflections.

It is about drawing clear boundaries, but still stay in a nice relationship with people...but empowering....And I would also always do more for the people than what I am paid for.... [If I would be paid] I would have a task description, which states that I do this and that and that. But when something else is needed, something I can do, then I would not send the people away, but I would just do it.

Both research participants establish a negative relationship between remuneration, professionalism on the one hand, and passionate commitment and relations of care on the other, which corresponds to dominant discourses about a masculinised, rational, detached, instrumental ethics versus a feminised, emotional, involved ethic of care (de Jong, 2017b). As research into professional social workers' responses to austerity and managerialism in the non-profit sector has shown, forms of resistance are also present within professional contexts. Some paid professional workers, for instance, subvert the logics of efficiency by offsetting its consequences with substantial amounts of unpaid overtime, "in order to meet higher goals of care for others in an increasingly uncaring society" (Baines, 2016, p. 136).

What becomes clear from the above, however, is that autonomy as well as the nature of relationships between what in mainstream NGOs would be considered 'clients' and 'providers', were key to the self-understanding and principles of the initiatives that we investigated. In the next section, we discuss the kind of relationship that the initiatives sought to establish between refugees, asylum seekers and those that volunteered to support them.

\subsection{Relationships and Governance}

The origin stories of the initiatives as told in the interviews revealed that not only a growing awareness of asylum seekers and refugees' needs was an important impetus for establishing the initiatives, but also the relationships that the founders had developed with refugees. The founder of Flucht nach Vorn established a relation to one young refugee in the context of her NGO work. As she explains: "Well, it wasn't like I had planned to initiate Flucht nach Vorn. It simply came from the need to help first this boy, then his four friends, and then all those others."
One PROSA founder recounted how in the context of his former job with an NGO he realised that the Austrian educational system excluded young asylum seekers because of its monolingual set up. As he explains, his awareness of this fundamental problem "became personalised with these very keen, ambitious, sympathetic young men" that he had met. In the case of Queer Base, the social space provided by the Rosa Lilla Villa (the LGBTQI social movement initiative that Queer Base is an offspring of), LGBTQI activists who were already based in Austria started to build closer relationships with LGBTQI asylum seekers and refugees. "Of course we became persons of trust for them. And then entirely different themes emerged. Then we started to talk about health issues. These are people with post-traumatic distress symptoms and I don't know what else." Finally, one of the founders of KAMA described the impact of the relationships she established in the context of her initial voluntary work for an NGO:

When one sits opposite to these people and talks to them, then, I mean I could not comprehend in what kind of situation these people live.... How silly is that? They sit there and wait. They cannot do anything, not pay rent, not buy food, they cannot participate in any processes. Yes, that was at first really outrage and bewilderment. And [the feeling that] one should be able to do something, and with that, it was clear anyways, that I would do something.

Research has highlighted the relevance of affect in the context of activism in support of refugees and asylum seekers (Rosenberger \& Winkler, 2014). Kynsilehto, in a study on solidarities found that emotions as "an integral part of activism" were "woven into the relational webs between people" (2017, p. 53). Sutter (2017) discusses the emergence of emotional politics of civic engagement for refugees in the most recent so-called refugee crisis through a case study of volunteers in a train station in Germany. He shows how the participants were able to create a framework of emotional practices, which was vital for the constitution of civic engagement in its early phases.

It is important, however, to emphasise that these affective responses were not articulated by our research participants as a politics of empathy or pity for asylum seekers and refugees. Instead, they generated a critique of inadequate state and third sector provision as well as national and international legal constraints. The activities of the initiatives were therefore not primarily conceived to make asylum seekers and refugees 'feel better', a sentiment discussed in research on volunteers in a Dutch asylum seeker centre in the Netherlands, who, in the face of the hard conditions, turned away from transforming external institutions towards transforming internal feelings (Larruina \& Ghorashi, 2016).

Some of our research participants' early relationships with refugees and asylum seekers were established in the context of their work for established NGOs. How- 
ever, the literature on majority-led professional NGOs is largely silent on relationality and affective politics, in contrast to social movement research. Only the literature on grassroots migrant-led and refugee community organisations (as well as on ethnic associations; cf. Cattacin \& Domenig, 2014) assumes stronger affective ties based on common experiences in relation to marginalisation based on citizenship status, racialisation, linguistic and regional affinity. Hence, the intersection between emotions, relationships and engagement that we found, cannot be adequately captured in this framework. None of the initiatives were grassroots migrant-led initiatives that had emerged as a collective response to the challenges of navigating in the so-called host country. However, in two of the initiatives, the founders had experienced forced migration in their youth or had a migration history in their families, and continued facing racialisation and discrimination, which facilitated the building of relationships with those accessing the programmes of their organisations. "These are people affected by racism. That is my common denominator with them", as a PROSA founder put it. However, across all of the initiatives, the focus was on establishing personal ties rather than professional relationships of provider and client.

One PROSA founder, for instance, explained that the relationships they seek to build with their students are characterised by fairness and equality and form part of a long-term commitment. In his view, this could not be established in the context of a service delivery NGO, which he described as one "where the young people come as clients...get a service and should go again". This emphasis had implications for the founders' views on the structures of governance of their organisations. The initiatives are neither migrant-led grassroots organisations, which have structures of self-governance, nor social movements with seek to maintain close links to their social base (though as Nyers, 2003, points out, solidarity between migrants and non-migrants within social movements is a continuous struggle that cannot be taken for granted). Nevertheless, we found that the founders were keen, yet again, to distance themselves from professionalised established NGOs with majority-dominated management structures.

Both PROSA founders emphasised that the alumni of the programme were encouraged to take an active role in the organisation. As one of the founders put it: "they are not like our objects, but should be our subjects". The founders of the other organisations shared similar reflections on including refugee "alumni" of their programme in the (emerging) governance structure of their organisations. Encouraging the transition from service user to organiser was an important way in which the organisations tried to address representation of refugees. At the same time, they did not fail to recognise that many who came to their organisations for support faced structural obstacles in developing themselves as leaders within the organisations. Also, they observed that principles of equality and empowerment were inevitably compromised by the structural inequalities that underpinned the need for their organisation in the first place. In the next section, we will return to the issues of system critiques, politics, and affective ties, but shift our focus from the relationships of the founders with asylum seekers and refugees, to the relationships emerging through volunteers' engagement with the initiative.

\subsection{Service Provision and System Critique}

As discussed above, the four organisations differed in the content and scope of their activities, ranging from education for refugees, to courses by refugees, from social meeting space to counselling and leisure time activities. Each of these projects had been set up in response to an emerging demand and a gap in the provision of existing services. We suggest that each organisation went beyond the services necessary for mere survival, such as shelter, or those intrinsically linked to the asylum process, such as legal advice services, as well as that what the state is legally obliged to supply, such as mandatory education. As Vickers has noted in the UK context, "the depoliticized provision of basic services to help refugees survive...stabilize[s] the asylum system by softening the impact of hardships caused by a lack of state support, thus provoking less resistance" (2016, p. 449). Providing opportunities for leisure time activities, safe spaces for sexual expression, and education beyond compulsory schooling, consciously and explicitly challenged the way migration regimes channel asylum seekers and refugees into 'bare life' (Owens, 2009). This is well illustrated with an example from the website of Flucht nach Vorn, which states that: "We are of the opinion that every human being, in addition to basic human rights, has the right to selfdevelopment and creativity" (Flucht nach Vorn, 2014). An article in a local newspaper about the initiative reinforced this point in slightly different terms: "Their vision is clear: not just the basic needs of young people should be met, they should also enjoy life" (Cetin, 2013).

Hence, we argue that the most significant commonality between the initiatives can only be detected when looking beyond the specificity of the activities offered by each of the initiatives and attending instead to the kind of space that they build. We suggest that each of the organisations, in their own way, create a space of encounter between refugees, asylum seekers, other migrants and non-migrants. We consider such spaces of encounter political in radical terms due to four reasons that we will discuss in turn below. First, as established above, the insistence on people's right to a social space of encounter, regardless of citizenship status challenges asylum seeker's position as only having the right to basic services. As Queer Base emphasised in their acceptance speech of the Bruno Kreisky Human Rights Prize 2017: "it is for us not just about protection for asylum seekers, but also about a good life without hostilities, either from the majority society or from communities of origin" (Queer Base-Welcome and Support for Lgbtiq Refugees, 2017). 
Secondly, the creation of spaces of encounter resists the politics of isolation and segregation to which especially asylum seekers are subject. With migration policies being geared towards an "organised disintegration" (Täubig, 2009, p. 58), or "policy-imposed liminality" (Piacentini, 2015, p. 436), these initiatives foster "integration" beyond the assimilationist hegemonic mode. In this context seemingly innocuous projects, such as facilitating courses taught by asylum seekers and refugees as in the case of $K A M A$, have a radical edge. As one founder explains:

It is a form of statement, when one is engaged in an area where one gets around the ban on working [for asylum seekers] and when one brings people who should actually disappear, who one doesn't see and who should be invisible, on a platform.

PROSA also illustrates this point in their selfpresentation, which states that "With our educational offer, we create at the same time a space that guarantees our participants security through a structured everyday life and the building of supporting and social relationships" (Sozialmarie, 2015).

Thirdly, building spaces of encounter creates new identifications and belongings. When KAMA introduces volunteers and aspiring refugee teachers to each other, there is from the beginning "not a Them and Us, but actually only a We", as one founder explains. In spaces of encounter connections are established that cross various boundaries (Vickers, 2016). A PROSA member told us that "it is actually about identification and the work that we do ends up being about the fact that people identify with each other". As Piacentini (2016) argues, through everyday encounters bonds of solidarity can be formed that transcend the nation-state as the locus of belonging and inclusion. This is important since "face-to-face interactions between citizens and migrants [in the context of volunteering] is one way to break out of the cycle of volatility", that characterises media-induced moments of empathy with refugees, which are frequently followed by phases of indifference and hostility (Karakayali, 2016; cf. Phillimore, 2012). Connections also foster social capital that empowers racialised, marginalised migrants and counter isolationist migration policies. At the same time, these spaces also provided the setting for building relationships of care and solidarity beyond likeness and likeability. Someone from Queer Base, for instance, described how the people that met each other also "become family [and] just like in a large family, there is a cousin where it is good to only see him once a year." This quote highlights the affective labour and the challenges that come with constructing new communities. Creating these spaces of encounter also means taking the dominant, majoritised community out of their comfort zone and segregated enclave. It thereby shifts the onus of integration from asylum seekers and refugees to the wider community and thinks about common desires for a better world.
Finally, these spaces of encounter can be places where relationships are established, where people who engage as volunteers can be outraged by structural injustices, similarly to the founders' first experiences. This is illustrated in a quote from a founder from Flucht nach Vorn:

One cannot work for refugees and then not be political or think that everything is all fine. It is not. Already the first time that one loses a friend because of a deportation, one cannot be apolitical anymore. And it is then not about small drawing workshops that one organises for sweet, small children.

This is in line with Bassel and Emejulu's observation that "solidarity both animates oppositional voluntary action and is the hoped-for outcome of this form of action" (2014, p. 133). We therefore suggest that these organisations manage "holding together the 'against' and the 'beyond"' (Dixon, 2014, p. 104). Their prefigurative politics of going beyond existing structures is coupled with "struggles against exploitation and oppression" (Dixon, 2014, p. 104, italics added). In contrast to the trend for social movements to move from "demanding" to "delivering" services as formalised NGOs (Gupta, 2014), these Austrian initiatives successfully manage, at least for now, to hold the two together in productive tension.

\section{Conclusion}

This article has analysed the organisational biographies of four new refugee support organisations in Austria, founded just before the summer of 2015. Based on interviews with their founders, as well as organisational and media literature, we have shown that their previous NGO and social movement experience formed a springboard for setting up their own organisations. Not only did it allow the founders to identify significant gaps in existing service provision and provided the space of confrontation with realities of the asylum system, which inspired a strong sense of outrage, it also led them to develop a political critique. This combination of factors inspired the founders to build organisations that occupy a middle space between established NGOs and social movements. Drawing on the social movement literature that has mapped areas of contention between social movements and NGOs, we demonstrated that the founders navigate these contentions by building structures of inclusive governance and maintaining personal relationships with 'service users' by creating a space of encounter.

Recognising the drawbacks and merits of both NGOs and social movements, the organisations moreover guard their autonomy, balance volunteerism with professionalism, and combine radical system critique with a reform of asylum and refugee services. Inevitably, this balancing act includes personal risks, such as of burnout, structural risks, such as co-optation and rapid growth, as well as financial risks. Nevertheless, we have argued 
that these four initiatives successfully combine system critique with a response to asylum seekers and refugees' needs, inspiring a new form of organisation that both delivers services and demands change. Each of the programmes offered by the four organisations insist on the right of asylum seekers and refugees to a life beyond bare existence and on creating spaces of encounter that challenge the intentional isolation of the asylum system and foster new political collectivities.

\section{Acknowledgements}

The authors want to thank the founders of the four organisations for sharing their experiences with us, as well as Herbert Langthaler, Irene Messinger, Sonja Moghaddari, Stephan Scheel, Vita Terry, the participants of the workshop "Flucht, Solidarität und Ökonomie" in Vienna (30 June-1 July 2017) and the anonymous reviewers for their helpful comments and suggestions. Open access funding provided by the University of Vienna.

\section{Conflict of Interests}

The authors declare no conflict of interests.

\section{References}

Ambrosini, M., \& Van der Leun, J. (2015) Introduction to the Special Issue: "Implementing Human Rights: Civil Society and Migration Policies", Journal of Immigrant \& Refugee Studies, 13(2), 103-115. doi:10.1080/15562948.2015.1017632

Ataç, I. (2015). Freiwilligenarbeit als Notnagel oder Neuformierung von Zivilgesellschaft? Kurswechsel: Zeitschrift für gesellschafts-, wirtschafts- und umweltpolitische Alternativen, 4, 80-84.

Ataç, I. (2016). 'Refugee Protest Camp Vienna': Making citizens through locations of the protest movement. Citizenship Studies, 20(5), 629-646.

Baines, D. (2016). Moral projects and compromise resistance: Resisting uncaring in nonprofit care work. Studies in Political Economy, 97(2), 124-142.

Bassel, K., \& Emejulu, A. (2014). Solidarity under austerity. Intersectionality in France and the United Kingsdom. Politics \& Gender, 10(1), 130-136.

Bauböck, R., \& Scholten, P. (2016). Introduction to the special issue "Solidarity in diverse societies: beyond neoliberal multiculturalism and welfare chauvinism": Coping with 'the progressive's dilemma'; nationhood, immigration and the welfare state. Comparative $\mathrm{Mi}$ gration Studies,4(4). doi:10.1186/s40878-016-0025-z

Bendaña, A. (2006). NGOs and social movements: A North/South divide? Civil Society and Social Movements Programme No 22. Geneva: United Nations Research Institute for Social Development.

Bloch, A., \& Schuster, L. (2002). Asylum and welfare: Contemporary debates. Critical Social Policy, 22(3), 393-414.
Castañeda, H. (2013). Medical aid as protest: Acts of citizenship for unauthorized im/migrants and refugees, Citizenship Studies, 17(2), 227-240.

Cattacin, S., \& Domenig, D. (2014). Why do transnationally mobile people volunteer? Insights from a Swiss case study. Voluntas, 25, 707-729.

Cetin, A. (2013, November 26). Wir wollen Kinder ermächtigen. Wiener Zeitung. Retrieved from http:// www.wienerzeitung.at/themen_channel/integration /gesellschaft/590022_Wir-wollen-Kinder-ermaechti gen.html

Cullen, P. P. (2009). Irish pro-migrant non-governmental organizations and the politics of immigration. Voluntas, 20, 99-128.

De Jong, S. (2017a). Refugees at work: (Ent-)Wertung von Wissen im Sozialen Sektor. In L. Karasz (Ed.), Migration: die Macht der Forschung: Kritische Wissenschaft in der Migrationsgesellschaft (pp. 247-262). Vienna: OeGB Verlag.

De Jong, S. (2017b). Complicit sisters: Gender and women's issues across North-South divides. Oxford: University of Oxford Press.

Diakonie. (2017). Über uns. Diakonie. Retrieved from https://diakonie.at/ueber-uns

Dixon, C. (2014). Another politics: Talking across today's transformative movements. Berkeley: University of California Press.

Erste Stiftung. (2013, June 28). Preis für soziale Integration der ERSTE Stiftung erstmals auch an österreichische Organisationen verliehen. OTS. Retrieved from https://www.ots.at/presseaussendung/OTS_201306 28_OTS0112/preis-fuer-soziale-integration-der-erste -stiftung-erstmals-auch-an-oesterreichische-organisa tionen-verliehen-bild

Fairbairn, B. (2001). Social movements and co-operatives: Implications for history and development. Review of International Co-operation, 94(1), 24-34.

Flucht nach Vorn (2014). Über uns. Ziele. Flucht nach Vorn. Retrieved from http://www.fluchtnachvorn. org/ziele

Gupta, S. (2014). From demanding to delivering development: challenges of NGO-led development in rural Rajasthan, India. Journal of South Asian Development, 9(2), 121-145.

Karakayali, S. (2016). Rights or philanthropy. Emotions and solidarity with refugees. Retrieved from https://www.compas.ox.ac.uk/2016/rights-orphilanthropy-emotions-of-solidarity-with-refugees

Kynsilehto, A. (2017). Mobilities, politics, and solidarities. Peace Review, 29(1), 48-54.

Langthaler, H., \& Trauner, H. (2009). Das österreichische Asylregime unter besonderer Berücksichtigung der Rolle zivilgesellschaftlicher Organisationen. SWSRundschau, 49(4), 446-467.

Larruina, R., \& Ghorashi, H. (2016). The normality and materiality of the dominant discourse: Voluntary work inside a Dutch asylum seeker center. Journal of Immigrant \& Refugee Studies, 14(2), 220-237. 
MacKenzie, R., Forde, C., \& Ciupijus, Z. (2012). Networks of support for new migrant communities: Institutional goals versus substantive goals? Urban Studies, 49(3), 631-647.

Martin, N. (2014). Spaces of hidden labor: Migrant women and work in nonprofit organizations. Gender, Place \& Culture, 21(1), 17-34.

Mauch, U. (2015, May 2). Die Initiative "Schule für alle" erhielt den ersten Preis der "SozialMarie". Kurier. Retrieved from https://kurier.at/leben/sozialmariezeichnet-prosa-fuer-asylwerber-aus/128.122.662

McGee, D., \& Walker, S. (2016). The combination of 'insider' and 'outsider' strategies in VSO-government parternships: The relationship between Refugee Action and the Home Office in the UK. Voluntary Sector Review, 7(1), 27-46.

Mora, C., \& Handmaker, J. (2014). Migrants' citizenship and rights: Limits and potential for NGOs' advocacy in Chile. In T. Truong, D. Gasper, J. Handmaker, \& S. Bergh (Eds.), Migration, gender and social justice, perspectives on human insecurity (pp. 281-290). Berlin and Heidelberg: Springer.

Nyers, P. (2003). Abject cosmopolitanism: The politics of protection in the anti-deportation movement. Third World Quarterly, 24(6), 1069-1093.

OE1. (2014, January 9). Asyl: Nur Wien hält Quote ein. Morgenjournal Ö1. Retrieved from http://oe1.orf.at/ artikel/362964

Owens, P. (2009). Reclaiming 'bare life'? Against Agamben on refugees. International Relations, 23(4), 567-582.

Petras, J. (1999). NGOs in the service of imperialism. Journal of Contemporary Asia, 29(4), 429-440.

Phillimore, J. (2012). Implementing Integration in the UK: Lessons for integration theory, policy and practice. Policy and Politics, 40(4), 525-545.

Phillips, N., \& Hardy, C. (1997). Managing multiple identities: Discourse, legitimacy and resources in the UK refugee system. Organization, 4(2), 159-185.
Piacentini, T. (2015). Missing from the picture? Migrant and refugee community organizations' responses to poverty and destitution in Glasgow. Community Development Journal, 50(3), 433-447.

Piacentini, T. (2016). Refugee solidarity in the everyday. Soundings: A Journal of Politics and Culture, 64, 57-61.

Queer Base-Welcome and Support for Lgbtiq Refugees. (2017). Retrieved from https://www.facebook.com/ QueerBaseVienna

Rosenberger, S., \& Winkler, J. (2014). Com/passionate protests: Fighting the deportation of asylum seekers. Mobilization. An International Quarterly, 19(2), 489-510.

Sozialmarie. (2015). PROSA-Projekt Schule für Alle! Sozialmarie. Retrieved from https://www. sozialmarie.org/ files/4340/pdf_en.pdf

Sutter, O. (2017). "Willkommen!" Emotionale Politiken des zivilgeselschaftlichen Engagements für Flüchtende. Zeitschrift für Volkskunde, 113(1), 3-23.

Täubig, V. (2009). Totale Institution Asyl. Empirische Befunde zu alltäglichen Lebensführungen in der organisierten Desintegration. Winheim: Juventa Verlag.

UNDOK. (2017). Presseinformation ZUGANG JETZT! Für ein selbstbestimmtes Leben von Asylwerber*innen in Österreich Informationskampagne der UNDOKAnlaufstelle. Retrieved from http://zugang-jetzt. undok.at/wp-content/uploads/sites/2/2016/11/Pres seinformation_UNDOK_ZugangJetzt.pdf

van Dyk, S., \& Misbach, E. (2016). Zur politischen Ökonomie des Helfens. Flüchtlingspolitik und Engagement im flexiblen Kapitalismus. Prokla. Zeitschrift für kritische Sozialwissenschaft, 183, 205-228.

Vickers, T. (2014). Developing an independent anti-racist model for asylum rights organizing in England. Ethnic and Racial Studies, 37(8), 1427-1447.

Vickers, T. (2016). Opportunities and limitations for collective resistance arising from volunteering by asylum seekers and refugees in Northern England. Critical Sociology, 42(3), 437-454.

\section{About the Authors}

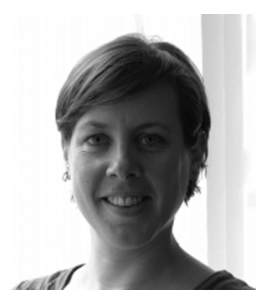

Sara de Jong $(\mathrm{PhD})$ is the co-lead of the Justice, Borders, Rights research stream and Research Fellow of the Strategic Research Area Citizenship \& Governance at The Open University (UK). In various research projects, she has analysed the politics of NGOs in the fields of migration, gender and development. From 2014-2016, she held a Marie Skłodowska-Curie Fellowship at the Department of Development Studies, University of Vienna with her project 'Employing the Cultural Broker in the Governance of Migration and Integration'.

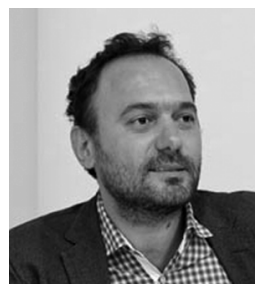

Ilker Ataç (PhD) is a research fellow at the Department of Political Science at the University of Vienna. His research focuses on citizenship and migration policies, social movements and civil society. Currently he works on access to social services for non-deported persons from a comparative perspective. He was a visiting professor in Politics of Labor Migration at the University Kassel and worked as a research fellow at the Institute for Migration Research and Intercultural Studies (IMIS), University of Osnabrück. 